\title{
PENGARUH KEPEMILIKAN MANAJERIAL DAN KEPEMILIKAN INSTITUSIONAL TERHADAP KEBIJAKAN HUTANG PERUSAHAAN DITINJAU DARI TEORI KEAGENAN (STUDI PADA PERUSAHAAN OTOMOTIF DAN ONDERDIL OTOMOTIF YANG GO PUBLIK DI BEI)
} Handoyo Wirastomo ${ }^{1}$ H.Muhammad $\mathrm{Ali}^{2}$

Fakultas Ilmu Sosial dan Politik Universitas Muhammadiyah Mataram handoyo.wirastomo@gmail.com ${ }^{1}$ Khaidiraliihsan@gmail.com ${ }^{2}$

\begin{abstract}
The purpose of this study is to empirically prove the effect of managerial ownership and institutional ownership on the company's debt policy. This research is based on previous research conducted by Wahidahwati (2001) which found that ownership structure affects the company's debt policy to reduce agency conflict. The focus of this research is manufacturing companies listed on the IDX. Sampling was done by purposive sampling method, and obtained a sample of 57 companies for three years. The analytical method used is multiple regression.
\end{abstract}

\section{PENGARUH KEPEMILIKAN MANAJERIAL DAN KEPEMILIKAN INSTITUSIONAL TERHADAP KEBIJAKAN HUTANG PERUSAHAAN DITINJAU DARI TEORI KEAGENAN (STUDI PADA PERUSAHAAN OTOMOTIF DAN ONDERDIL OTOMOTIF YANG GO PUBLIK DI BEI)}

\begin{abstract}
ABSTRAK
Tujuan dari penelitian ini adalah untuk membuktikan secara empiris pengaruh kepemilikan manajerial dan kepemilikan institusional terhadap kebijakan hutang perusahaan. Penelitian ini berdasarkan penelitian sebelumnya yang dilakukan oleh Wahidahwati (2001) yang menemukan bahwa struktur kepemilikan berpengaruh terhadap kebijakan hutang perusahaan untuk mengurangi konflik keagenan. Fokus dari penelitian ini adalah perusahaan manufaktur yang teradaftar di BEI. Pengambilan sampel dilakukan dengan metode purposive sampling, dan diperoleh 57 sampel perusahaan selama tiga tahun. Metode analisis yang digunakan adalah regresi berganda.
\end{abstract}

Kata kunci: Kepemilikan Manajerial, Kepemilikan Institusional, Teori Keagenan

\section{A. Pendahuluan}

Teori keagenan menjelaskan bahwa kepentingan manajemen dan kepentingan pemegang saham dimungkinkan untuk bertentangan. Penunjukan manajer oleh pemegang saham untuk mengelola perusahaan dalam kenyataannya seringkali menghadapi masalah dikarenakan tujuan perusahaan berbenturan dengan tujuan pribadi manajer. Dengan kewenangan yang dimiliki, manajer bisa melakukan tindakan yang lebih menguntungkan dirinya sendiri dengan mengorbankan kepentingan para pemegang saham sebagai pemilik perusahaan. Pemegang saham tentu saja tidak menyukai tindakan manajer tersebut, karena manajemen sering melakukan pengeluaran, sementara pengeluaran tersebut akan menambah kos perusahaan yang menyebabkan penurunan keuntungan perusahaan dan penurunan deviden yang akan diterima. Pemegang saham 
menginginkan agar kos tersebut dibiayai oleh utang, tetapi manajer tidak menyukai dengan alasan bahwa utang mengandung resiko yang tinggi.

Teori keagenan muncul karena adanya perbedaan kepentingan antara pemegang saham, debtholders dan manajer. Pemegang saham menginginkan timbal balik hasil yang sesuai dengan risiko yang ditanggungnya yang terkait juga dengan biaya yang dikeluarkannya. Pihak debtholders menginginkan dana yang dipinjamkannya mendapat imbal hasil yang sesuai dengan kesepakatan, risiko serta pengembalian yang tepat waktu. Manajemen juga mempunyai kepentingan untuk memperoleh imbalan yang sesuai dengan kemampuan yang sudah dikeluarkannya. Pemegang saham serta debtholders berharap manajemen dapat mengambil kebijakan perusahaan terutama kebijakan keuangan yang menguntungkan pemegang saham dan debtholders. Bila keputusan yang diambil oleh manajemen merugikan bagi pemegang saham dan debtholders maka akan terjadi masalah yang disebut konflik agensi atau masalah keagenan.

Konflik kepentingan antara manajer dan pemegang saham dapat diminimumkan dengan suatu mekanisme pengawasan yang dapat mensejajarkan kepentingankepentingan yang terkait tersebut. Akibat dari munculnya mekanisme pengawasan tersebut menyebabkan timbulnya suatu kos yang disebut agency cost. Ada beberapa pendekatan yang dapat dilakukan untuk mengurangi agency cost. Pertama, dengan meningkatkan kepemilikan dari dalam (insider ownership) atau kepemilikan manajerial, menurut Jensen dan Meckling (1976) penambahan kepemilikan manajerial memiliki keuntungan untuk mensejajarkan kepentingan manajer dan pemegang saham, sehingga manajer akan akan merasakan langsung manfaat dari keputusan yang diambil dengan benar dan akan merasakan kerugian sebagai konsekuensi dari pengambilan keputusan yang salah. Kedua, dengan menggunakan kebijakan hutang Easterbrook (1984) dalam Ismiyanti dan Hanafi (2003) berargumen bahwa pemegang saham akan melakukan monitoring terhadap manajemen namun bila biaya monitoring tersebut terlalu tinggi maka mereka akan menggunakan pihak ketiga (debtholders dan atau bondholders) untuk membantu mereka melakukan monitoring. Debtholders yang sudah menanamkan dananya di perusahaan dengan sendirinya akan berusaha melakukan pengawasan terhadap penggunaan dana tersebut. Ketiga, melalui Dividend Payout Ratio (DPR) atau rasio deviden terhadap laba bersih. Cruchley dan Hansen (1989) dalam Wahidahwati(2001) menyatakan bahwa pembayaran deviden akan menjadi alat monitoring sekaligus bonding bagi manajemen, karena dengan pembayaran deviden akan mengurangi cash flow perusahaan akibatnya perusahaan dalam memenuhi operasinya akan mencari alternatif sumber pendanaan yang relevan. Keempat, dengan cara mengaktifkan monitoring melalui investor institusional (Moh'd et al,1998) dalam Wahidahwati(2001). Adanya kepemilikan oleh institutional investor seperti perusahaan asuransi, bank, perusahaan investasi, dan kepemilikan institusi lain akan mendorong peningkatan pengawasan yang lebih optimal terhadap kinerja manajemen, karena kepemilikan saham mewakili suatu sumber kekuasaaan yang dapat digunakan untuk mendukung atau sebaliknya terhadap keberadaan manajemen. Penelitian mengenai hubungan struktur kepemilikan dengan hutang perusahaan telah dilakukan oleh banyak peneliti dan mereka menemukan hasil yang berbeda. Agrawal dan Mendelker (1987) sebagaimana diungkapkan oleh Wahidahwati (2001), menemukan hubungan positif antara kepemilikan manajerial dengan rasio hutang perusahaan. Merhan (1992) dalam Wahidawati (2001) menyatakan bahwa terdapat hubungan positif antara kepemilikan manajerial dengan rasio hutang perusahaan. Sedangkan penelitian Jensen et al (1992), 
sebagaimana diungkapkan pula oleh Wahidawati (2001), menemukan hubungan negatif antara presentase saham yang dipegang oleh manajer dengan rasio hutang perusahaan. Penelitian Moh'd et al (1998), menemukan bukti bahwa kepemilikan saham oleh pihak institusional, kepemilikan saham oleh pihak manajerial dan shareholders dispersion mempunyai pengaruh negatif terhadap rasio hutang perusahaan.

Penelitian tentang pengaruh struktur kepemilikan terhadap kebijakan hutang juga telah dilakukan oleh beberapa peneliti di Indonesia. Wahidahwati (2001) menemukan bukti bahwa kepemilikan manajerial dan kepemilikan institusional berpengaruh negatif terhadap kebijakan hutang. Penelitian Tarjo (2005) menemukan bukti bahwa kepemilikan manajerial mempunyai pengaruh negatif terhadap level hutang. Kim dan Sorenson (1986) dalam Ismiyanti dan Hanafi (2003), menyatakan hubungan positif antara kepemilikan manajerial dengan hutang. Studi tentang pengaruh struktur kepemilikan terhadap hutang perusahaan yang dilakukan diluar negeri maupun di Indonesia menunjukkan hasil penelitian yang beragam. Ketidak konsistenan hasil penelitian memperlihatkan adanya kecenderungan bahwa struktur modal tidak hanya ditentukan oleh jumlah hutang dan modal saja tetapi juga dipengaruhi oleh persentase kepemilikan dari pihak manajer dan institusional (Jensen dan Meckling, 1976), sehingga kepemilikan manajerial dan kepemilikan institusional dapat mempengaruhi keputusan pencarian dana apakah melalui hutang atau right issue. Jika pendanaan diperoleh melalui hutang berarti rasio hutang terhadap modal akan meningkat, sehingga akhirnya akan meningkatkan risiko kebangkrutan terhadap perusahaan.

Penelitian ini didasarkan dari penelitian Wahidahwati (2001) yang meneliti pengaruh kepemilikan manajerial dan kepemilikan institusional terhadap kebijakan hutang perusahaan : sebuah perspektive theory agency. Berbeda dengan penelitian sebelumnya, penelitian ini menambahkan variabel profitabilitas dan menambah periode pengamatan menjadi tiga tahun

\section{B. METODE PENELITIAN}

\section{Jenis Penelitian}

Sesuai dengan tujuan penelitian, yaitu untuk menganalisis pengaruh kepemilikan manajerial dan kepemilikan institusional terhadap kebijakan hutang perusahaan, maka jenis penelitian yang digunakan adalah hypothesis testing. Hypothesis testing merupakan suatu penelitian yang sudah memiliki kejelasan dan gambaran. Pengujian hipotesis dimaksudkan untuk menjelaskan fenomena dalam bentuk hubungan antar variabel (Indriantoro dan Supomo, 2002:89). Penelitian ini mengidentifikasikan fakta atau peristiwa sebagai variabel yang dipengaruhi (variabel dependen) dan melakukan penyelidikan terhadap variabel-variabel yang mempengaruhi (variabel independen).

\section{Populasi dan Sampel}

Populasi merupakan kelompok orang atau sesuatu yang memiliki karakteristik tertentu yang ingin diteliti oleh peneliti (Indriantoro dan Supomo, 2002:115). Populasi yang akan diamati dalam penelitian ini adalah seluruh perusahaan manufakur yang terdaftar di Bursa Efek Indonesia (BEI) periode 2006 sampai 2008 yang melaporkan laporan keuangan secara lengkap dan dipublikasikan pada Indonesian Capital Maket Directory (ICMD) sedangkan pemilihan sample menggunakan purpose sampling Kriteria-kriteria pengambilan sampel antara lain:

1. Perusahaan Otomotif dan Onderdil Otomotif yang telah terdaftar di BEI berturut-turut selama tahun 2006 sampai 2008 
2. Perusahaan Otomotif dan Onderdil Otomotif yang mempunyai laporan keuangan secara kontinue selama tahun 2006 sampai 2008.

3. Perusahaan Otomotif dan Onderdil Otomotif yang mempunyai prosentase kepemilikan saham oleh pihak manajerial (direktur dan komisaris) pada laporan keuangan tahun 2006 sampai 2008.

4. Perusahaan Otomotif dan Onderdil Otomotif yang mempunyai prosentase kepemilikan saham oleh institusional pada laporan keuangan tahun 2006 sampai 2008.

5. Perusahaan Otomotif dan Onderdil Otomotif yang mempunyai data hutang jangka panjang.

\section{Sumber dan Jenis Data}

Data penelitian yang digunakan adalah data sekunder berupa laporan keuangan masing-masing perusahaan publik yang terdaftar di BEI dan telah terpilih sebagai sampel penelitian. Sumber data sekunder adalah sumber data penelitian yang diperoleh peneliti secara tidak langsung melalui media perantara, yang dapat berupa bukti, catatan, atau laporan historis yang telah tersusun dalam arsip (data dokumenter), baik yang dipublikasikan maupun yang tidak dipublikasikan (Indriantoro dan Supomo, 2002:147). Pengumpulan data menggunakan teknik dokumentasi. Data tersebut diperoleh dari Indonesian Capital Market Directory (ICMD)

\section{Analisis dan Pembahasan}

Agar model dapat dianalisis serta memberikan hasil yang representative dan salah satu syarat untuk bisa menggunakan persamaan regresi berganda adalah terpenuhinya asumsi klasik. Sebab jika kita tidak mengidentifikasi asumsi-asumsi dari regresi dan korelasi berganda maka kita akan mendapatkan hasil yang bias (sporios regression and sporios correlation). Untuk mendapatkan nilai pemeriksa yang tidak bias dan efisien (Best Linear Unbias Estimator/BLUE) dari satu persamaan regresi berganda dengan metode kuadrat terkecil (Least Squares) perlu dilakukan pengujian untuk mengetahui model regresi yang dihasilkan memenuhi persyaratan asumsi klasik.

Persyaratan asumsi klasik yang harus dipenuhi adalah:

1. Berdistribusi Normal. Distribusi normal merupakan distribusi teoritis dari variabel random yang kontinyu (Dajan, 1986:72). Pengujian tehadap gejala normalitas dilakukan untuk mengetahui apakah dalam model regresi, variabel dependen, variabel independen, atau keduanya mempunyai distribusi normal atau tidak.

2. Non-autokorelasi. Artinya, bahwa kesalahan atau gangguan yang masuk ke dalam fungsi regresi populasi adalah random atau tak berkorelasi.

3. Non-multikolinearitas. Artinya, antara variabel independen yang satu dengan variabel yang lain dalam model regresi tidak saling berhubungan secara sempurna atau mendekati sempurna.

4. Homoskedastisitas. Artinya, varians variabel independen adalah konstan (sama) untuk setiap nilai tertentu variabel independen.

Dalam penelitian ini digunakan empat buah alat uji yaitu:

\section{1) Uji Normalitas}

Distribusi normal merupakan distribusi teoritis dari variable random yang kontinyu (Dajan, 1986). Kurva yang menggambarkan distribusi normal adalah kurva normal yang berbentuk simetris. Untuk menguji apakah sampel penelitian merupakan jenis distribusi normal maka digunakan pengujian normal probability plot of standardized residual sesuai yang terlihat pada figure 4.1, menunjukkan bahwa titik titik menyebar di sekitar garis diagonal dan penyebarannya mengikuti arah garis diagonal. Dengan demikian dapat 
dinyatakan bahwa penyebaran data penelitian mendekati normal atau memenuhi asumsi normalitas.

\section{Normal P-P Plot of Regression Standardized Residual}

Dependent Variable: Debt.Y

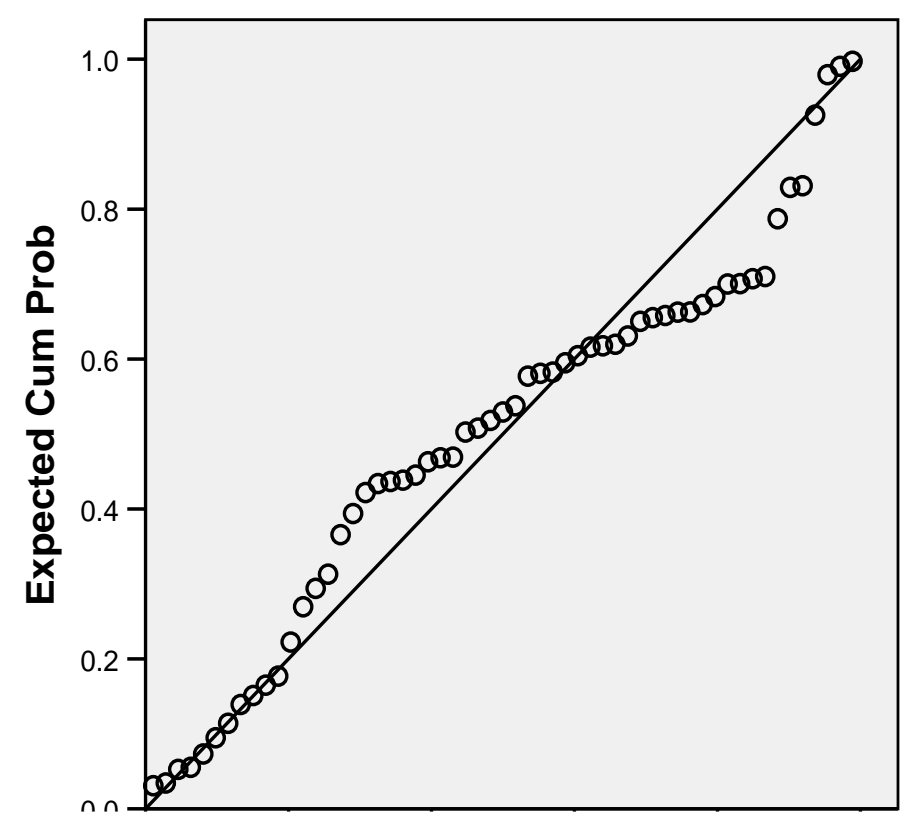

\section{2) Uji Autokorelasi}

Asumsi autokorelasi didefinisikan sebagai terjadinya korelasi diantara data pengamatan, dimana munculnya suatu data dipengaruhi oleh oleh data sebelumnya (Gujarati,1997: 202 ). Adanya suatu autokorelasi bertentangan dengan salah satu asumsi dasar dari regresi berganda yaitu tidak adanya korelasi diantara galat acaknya. Artinya jika ada autokorelasi maka dapat dikatakan bahwa koefisien korelasi yang diperoleh kurang akurat. Untuk mengdeteksi adanya autokorelasi digunakan uji Durbin-Watson yang bisa dilihat dari hasil uji regresi berganda. Berikut hasil perhitungan DW dengan menggunakan regresi :

Tabel 7 Pengujian Asumsi Autokorelasi dari variabel independen :

Pengaruh Kepemilikan Manajerial (X1), Kepemilikan Institusional (X2), serta variabel kontrol : Pembayaran Deviden (X3), Ukuran Perusahaan (X4), Struktur Aktiva (X5), Earning Volality (X6), Stock Volality (X7), dan Profitabilitas (X8) terhadap variabel independen Kebijakan hutang (Y).

Tabel 7 Uji Autikorelasi

\begin{tabular}{|c|c|c|c|c|c|c|}
\hline $\mathrm{N}$ & $\mathrm{dl}$ & $\mathrm{Du}$ & 4- & 4-dl & Dw & Interpret \\
\hline
\end{tabular}


Jl. KH. Ahmad Dahlan No.1, Pagesangan, Kec. Mataram, Kota Mataram, Nusa Tenggara Barat

\begin{tabular}{|c|c|c|c|c|c|c|c|}
\hline o & & & & $\mathrm{du}$ & & & asi \\
\hline 1 & Nil & 1.1 & 1.6 & 2.3 & 2.8 & 2.6 & $\begin{array}{l}\text { Tidak } \\
\text { ada } \\
\text { autokorel } \\
\text { asi }\end{array}$ \\
\hline
\end{tabular}

\section{3) Uji Multikolinearitas}

Pengujian terhadap multikolinearitas ini dilakukan untuk mengetahui apakah ada korelasi yang serius antara variabel independen (X) yang digunakan dalam model persamaan regresi. Untuk mendeteksi adanya multikolinearitas dapat dilihat dari Variance Inflation Factor (VIF). Apabila nilai VIF > 10 maka terjadi multikolinearritas dan sebaliknya apabila VIF < 10 maka tidak terjadi multikolinearitas (Ghazali, 2005:92). Dalam penelitian ini diperoleh VIF seperti pada tabel 8 sebagai berikut :

Tabel 8 Uji Multikolinearitas Variance Inflation Factor (VIF)

\begin{tabular}{|l|c|c|}
\hline Variabel Independen & NILAI VIF & KETERANGAN \\
\hline Kepemilikan Manajerial (X1) & 2.193 & Tidak ada indikasi Kolinearitas antar variabel \\
\hline $\begin{array}{l}\text { Kepemilikan Institusional } \\
(\mathrm{X} 2)\end{array}$ & 3.371 & Tidak ada indikasi Kolinearitas antar variabel \\
\hline Pembayaran Dividen (X3) & 1.132 & Tidak ada indikasi Kolinearitas antar variabel \\
\hline Ukuran Perusahaan (X4) & 2.204 & Tidak ada indikasi Kolinearitas antar variabel \\
\hline Struktur Aktiva (X5) & 1.113 & Tidak ada indikasi Kolinearitas antar variabel \\
\hline Earning Volatility (X6) & 1.867 & Tidak ada indikasi Kolinearitas antar variabel \\
\hline Stock Volatility (X7) & 3.042 & Tidak ada indikasi Kolinearitas antar variabel \\
\hline Profitabilitas (X8) & 1.613 & Tidak ada indikasi Kolinearitas antar variabel \\
\hline
\end{tabular}

Sumber : Data Sekunder yang diolah

Keterangan : $\quad$-Jumlah data (observasi) $=57$

-Dependent Variabel Kebijakan Hutang

Dari tabel tersebut dapat disimpulkan bahwa untuk semua variable tidak terjadi multikolinearitas dengan ditunjukkan nilai VIF lebih kecil dari 10.

\section{4) Uji Heteroskedastisitas}

Heteroskedastisitas akan mengakibatkan penaksiran koefisien-koefisien regresi menjadi tidak efisien. Hasil penaksiran akan menjadi kurang dari semestinya. Heteroskedastisitas bertentangan dengan salah satu asumsi dasar regresi linear, yaitu bahwa variasi residual sama untuk semua pengamatan atau disebut Homoskedastisitas (Gujarati, 1997:201). Menurut Santoso (2000:201) dasar pengambilan keputusan apakah terjadi Heterokedastisitas adalah sebagai berikut : 
a) Jika ada pola tertentu, seperti titik-titik (poin-poin) yang membentuk suatu pola tertentu yang teratur (bergelombang, menyebar kemudian menyempit) maka telah terjadi Heterokedastisitas.

b) Jika tidak ada pola yang jelas, seperti titik-titik di atas dan di bawah angka 0 pada sumbu Y maka tidak terjadi Heterokedastisitas. Berdasarkan hasil analisis terhadap keempat asumsi ekonometrik di atas maka terhadap data layak untuk dilakukan pengujian statistik.

\section{Scatterplot}

\section{Dependent Variable: Debt.Y}

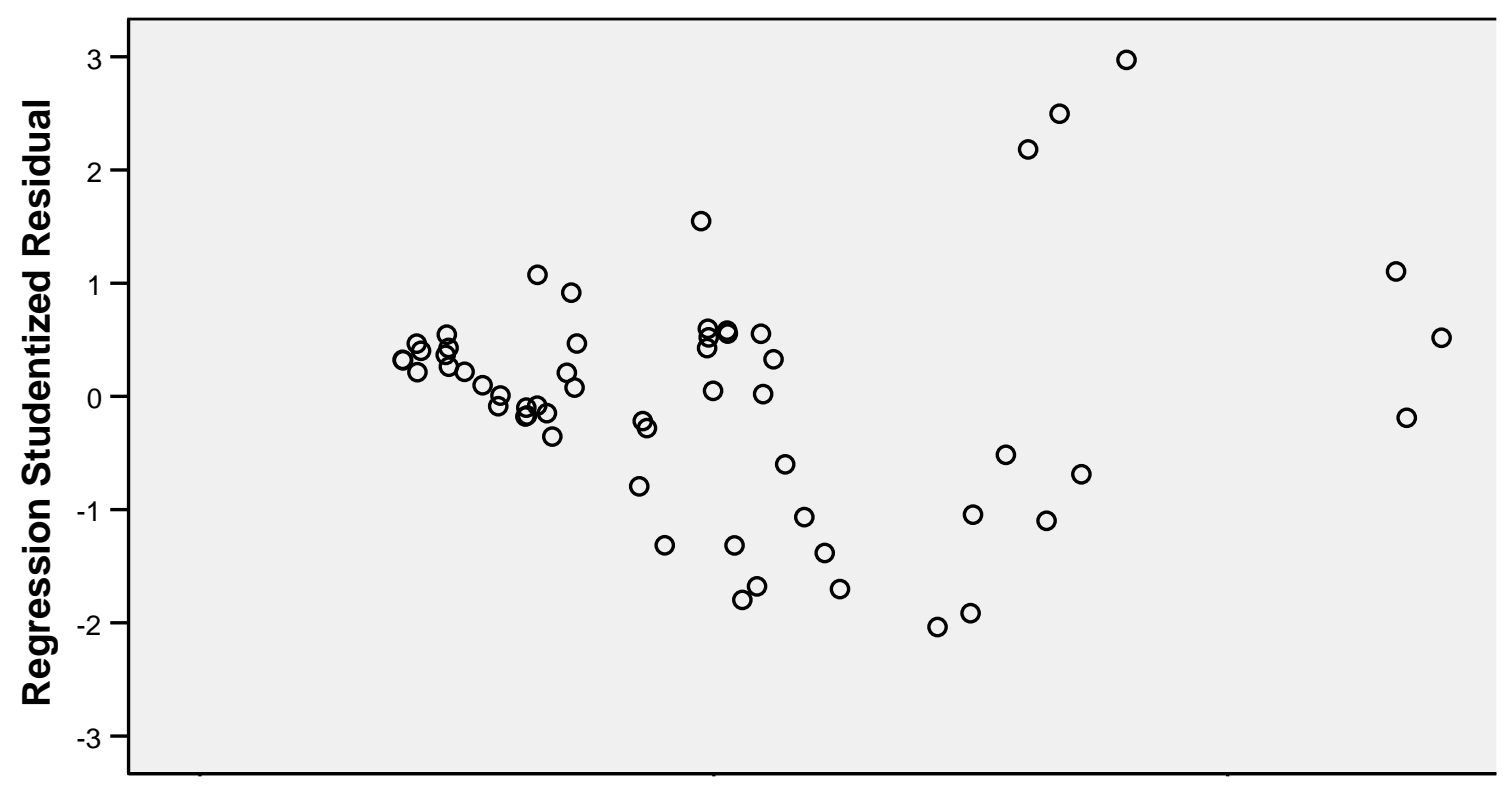

Pada grafik tidak terlihat bahwa terdapat pola yang jelas, karena titik-titik menyebar di atas dan di bawah angka 0 pada sumbu Y, sehingga dapat dikatakan bahwa pada model proporsi ini tidak terjadi gejala heterokedastisitas. Berdasarkan hasil analisis terhadap keempat asumsi ekonometrik di atas maka terhadap data layak untuk dilakukan pengujian statistik.

\section{b. Pengujian Hipotesis}

Kaidah pengujian signifikansi : Program SPSS

1) Jika nilai probabilitas 0,05 lebih kecil atau sama dengan nilai probabilitas Sig atau $[0,05$ $\leq$ Sig ], maka Ho diterima dan Ha ditolak, artinya tidak signifikan.

2) 2) Jika nilai probabilitas 0,05 lebih besar atau sama dengan nilai probabilitas Sig atau $[0,05 \geq$ Sig $]$, maka Ho ditolak dan Ha diterima, artinya signifikan.

Adapun hipotesis yang akan diuji dalam penelitian ini adalah sebagai berikut: 
1) Hipotesis untuk pengujian secara serentak (simultan):

H1 : Kepemilikan manajerial (X1) dan kepemilikan institusional (X2) berpengaruh signifikan terhadap kebijakan hutang perusahaan (Y) secara simultan

Pengujian secara serentak (simultan) ditunjukkan dalam Tabel

11. Hipotesis penelitian yang akan diuji, yaitu :

H1o: Kepemilikan manajerial dan kepemilikan institusional tidak berpengaruh signifikan terhadap kebijakan hutang perusahaan secara simultan.

H1a: Kepemilikan manajerial dan kepemilikan institusional berpengaruh signifikan terhadap kebijakan hutang perusahaan secara simultan.

2) Hipotesis untuk pengujian secara parsial :

-H2a : Kepemilikan manajerial (X1) berpengaruh signifikan dan berhubungan negatif terhadap kebijakan hutang perusahaan (Y) secara parsial

- H2b : Kepemilikan institusional (X2) berpengaruh signifikan dan berhubungan negatif terhadap kebijakan hutang perusahaan (Y) secara parsial

Pengujian secara parsial ditunjukkan dalam Tabel 12. Hipotesis penelitian yang akan diuji, yaitu :

Ho2a : Kepemilikan manajerial tidak berpengaruh signifikan dan tidak berhubungan negatif terhadap kebijakan hutang perusahaan secara parsial.

$\mathrm{Ha} 2 \mathrm{a}$ : Kepemilikan manajerial berpengaruh signifikan dan berhubungan negatif terhadap kebijakan hutang perusahaan secara parsial.

Ho2b : Kepemilikan institusional tidak berpengaruh signifikan dan tidak berhubungan negative terhadap kebijakan hutang perusahaan secara parsial.

$\mathrm{Ha} 2 \mathrm{~b}$ : Kepemilikan berpengaruh signifikan dan berhubungan negative terhadap kebijakan hutang perusahaan secara parsial.

Dalam pengolahan data dengan menggunakan regresi linear, dilakukan beberapa tahapan untuk mencari hubungan antara variable independen, variabel kontrol dan variabel dependen, melalui hubungan Variabel Kepemilikan Manajerial (X1), Kepemilikan Institusional (X2), serta variabel kontrol : Pembayaran Deviden (X3), Ukuran Perusahaan (X4), Struktur Aktiva (X5), Earning Volality (X6), Stock Volality (X7) dan Profitabilitas (X8) terhadap Kebijakan hutang (Y). Hasil regresi dapat dilihat pada tabel dibawah ini :

\begin{tabular}{|l|c|c|c|c|}
\hline \multicolumn{1}{|c|}{ Variabel } & $\begin{array}{c}\text { Unstandardi } \\
\text { zed } \\
\text { Coefficients } \\
(\mathrm{B})\end{array}$ & $\begin{array}{c}\mathrm{T} \\
\text { hitung }\end{array}$ & Sig. & Keterangan \\
\hline $\begin{array}{l}\text { (Constant) } \\
\text { Kepemilikan Manajerial } \\
(\mathrm{X} 1)\end{array}$ & -1.392 & & & \\
\hline $\begin{array}{l}\text { Kepemilikan Institusional } \\
(\mathrm{X} 2)\end{array}$ & 0.328 & 5.180 & 0.000 & Signifikan \\
\hline Pembayaran Dividen (X3) & -0.004 & 2.165 & 0.035 & Signifikan \\
\hline Ukuran Perusahaan (X4) & -0.036 & -1.126 & 0.266 & Tidak \\
\hline Struktur Aktiva (X5) & 0.571 & 0.953 & 0.345 & Signifikan \\
\hline
\end{tabular}


Jl. KH. Ahmad Dahlan No.1, Pagesangan, Kec. Mataram, Kota Mataram, Nusa Tenggara Barat

\begin{tabular}{|l|l|l|l|l|}
\hline & & & & Signifikan \\
\hline Earning Volatility (X6) & $8.15 \mathrm{E}-013$ & 4.150 & 0.000 & Signifikan \\
\hline Stock Volatility (X7) & 3.979 & 1.810 & 0.077 & $\begin{array}{l}\text { Tidak } \\
\text { Signifikan }\end{array}$ \\
\hline Profitabilitas (X8) & 9.464 & 2.162 & 0.036 & Signifikan \\
\hline $\begin{array}{l}\text { R=0.923 } \\
\text { R Square=0.853 }\end{array}$ & & & \\
F Hitung=34.681 & & & \\
Sign. F=0.000 \\
$\square=0.05$
\end{tabular}

Sumber : Data Sekunder yang diolah

Keterangan : $\quad$-Jumlah data (observasi) $=57$

-Dependent Variabel Kebijakan Hutang Y

*Signifikan pada level $5 \%$

Variabel tergantung pada regresi ini adalah Kebijakan hutang (Y) sedangkan variabel bebasnya adalah Kepemilikan Manajerial (X1), Kepemilikan Institusional (X2), serta variabel kontrolnya adalah Pembayaran Deviden

(X3), Ukuran Perusahaan (X4), Struktur Aktiva (X5), Earning Volality (X6), dan Stock

Volality (X7). Model regresi berdasarkan hasil analisis di atas adalah

$\mathrm{Y}=\mathbf{- 1 . 3 9 2}+\mathbf{0 . 3 2 8} \mathrm{X} 1+\mathbf{0 . 0 3 3 X} 2-\mathbf{0 . 0 0 4 X} 3-\mathbf{0 . 0 3 6} \mathrm{X} 4+\mathbf{0 . 5 7 1} \mathrm{X} 5+$

8.15E-013X6 + 3.979X7 + 9.464 + e

Tampak pada persamaan tersebut menunjukkan angka yang signifikan pada Kepemilikan

Manajerial (X1), Kepemilikan Institusional (X2), Pembayaran Deviden (X3), Ukuran

Perusahaan (X4), dan Earning Volality (X6) dan Profitabilitas (X8) sedangkan Ukuran

Perusahaan (X4), Struktur Aktiva (X5), dan Stock Volality (X7) tidak menunjukkan nilai yang signifikan. Adapun interpretasi dari persamaan tersebut adalah

1 . bo $=-1.392$

Nilai konstan ini menunjukkan bahwa apabila tidak ada Variabel Kepemilikan

Manajerial, Kepemilikan Institusional, Pembayaran Deviden, Ukuran Perusahaan,

Struktur Aktiva, Earning Volality, dan Stock Volality (X1, X2, X3, X4, X5, X6, X7, dan

X8=0), maka Kebijakan hutang (Y) sebesar 1.392 Dalam arti kata Kebijakan hutang (Y) sebesar 1.392 sebelum atau tanpa adanya Variabel Kepemilikan Manajerial, Kepemilikan Institusional, Pembayaran Deviden, Ukuran Perusahaan, Struktur Aktiva, Earning Volality, Stock Volality, dan Profitabilitas (X1, X2, X3, X4, X5 X6, X7, dan X8)= 0).

2. $\mathrm{b} 1=0.328$

Nilai parameter atau koefisien regresi b1 ini menunjukkan bahwa setiap variable Kepemilikan Manajerial meningkat 1 kali, maka Kebijakan hutang (Y) akan meningkat sebesar 0.328 kali atau dengan kata lain setiap peningkatan Kebijakan hutang (Y) dibutuhkan variabel Kepemilikan Manajerial sebesar 0.328, dengan asumsi variabel bebas yang lain tetap (X2, X3, X4, X5, X6, X7, dan X8)=0) atau Cateris Paribus. 3. $\mathrm{b} 2=0.033$

Nilai parameter atau koefisien regresi b2 ini menunjukkan bahwa setiap variable Kepemilikan Institusional meningkat 1 kali, maka Kebijakan hutang (Y) akan meningkat sebesar 0.033 kali atau dengan kata lain setiap peningkatan Kebijakan hutang (Y) 
dibutuhkan variable Kepemilikan Institusional sebesar 0.033 dengan asumsi variabel bebas yang lain tetap (X1, X3, X4, X5, X6, X7, dan X8=0) atau Cateris Paribus. 4. $\mathrm{b} 3=-0.004$

Nilai parameter atau koefisien regresi b3 ini menunjukkan bahwa setiap variable Pembayaran Deviden meningkat 1 kali, maka Kebijakan hutang (Y) akan menurun sebesar 0.004 kali atau dengan kata lain setiap penurunan Kebijakan hutang (Y) dibutuhkan variabel Pembayaran Deviden sebesar 0.004, dengan asumsi variabel bebas yang lain tetap (X1, X2, X4, X5, X6, X7, dan $\mathrm{X} 8=0$ ) atau Cateris Paribus.

$5 . \mathrm{b} 4=-0.036$

Nilai parameter atau koefisien regresi b4 ini menunjukkan bahwa setiap variable Ukuran Perusahaan meningkat 1 kali, maka Kebijakan hutang (Y) akan menurun sebesar 0.036 kali atau dengan kata lain setiap penurunan Kebijakan hutang (Y) dibutuhkan variable Ukuran Perusahaan sebesar 0.036, dengan asumsi variabel bebas yang lain tetap (X1, X2, $\mathrm{X} 3, \mathrm{X} 5, \mathrm{X} 6, \mathrm{X} 7$, dan X8=0) atau Cateris Paribus.

$6 . \mathrm{b} 5=0.571$

Nilai parameter atau koefisien regresi b5 ini menunjukkan bahwa setiap variable Struktur Aktiva meningkat 1 kali, maka Kebijakan hutang (Y) akan menurun sebesar 0.571 kali atau dengan kata lain setiap penurunan Kebijakan hutang (Y) dibutuhkan variable Struktur Aktiva sebesar 0.571, dengan asumsi variabel bebas yang lain tetap (X1, X2, $\mathrm{X} 3, \mathrm{X} 4, \mathrm{X} 6, \mathrm{X} 7$, dan $\mathrm{X} 8=0$ ) atau Cateris Paribus.

7. $\mathrm{b} 6=8.15 \mathrm{E}-013$

Nilai parameter atau koefisien regresi b6 ini menunjukkan bahwa setiap variable Earning Volality meningkat 1 kali, maka Kebijakan hutang (Y) akan meningkat sebesar 8.15E013

kali atau dengan kata lain setiap peningkatan Kebijakan hutang (Y) dibutuhkan variable Earning Volality sebesar 8.15E-013, dengan asumsi variabel bebas yang lain tetap (X1, $\mathrm{X} 2, \mathrm{X} 3, \mathrm{X} 4, \mathrm{X} 5, \mathrm{X} 7$, dan X8) =0) atau Cateris Paribus.

8. $\mathrm{b} 7=3.979$

Nilai parameter atau koefisien regresi b7 ini menunjukkan bahwa setiap variable Stock Volality meningkat 1 kali, maka Kebijakan hutang (Y) akan meningkat sebesar 3.979 kali atau dengan kata lain setiap peningkatan Kebijakan hutang (Y) dibutuhkan variable Stock Volality sebesar 3.979, dengan asumsi variabel bebas yang lain tetap (X1, X2, X3, $\mathrm{X} 4, \mathrm{X} 5, \mathrm{X} 6$, dan X8 = 0) atau Cateris Paribus.

8. $\mathrm{b} 8=9.464$

Nilai parameter atau koefisien regresi b7 ini menunjukkan bahwa setiap variable Profitabilitas meningkat 1 kali, maka Kebijakan hutang (Y) akan meningkat sebesar 9.464 kali atau dengan kata lain setiap peningkatan Kebijakan hutang (Y) dibutuhkan variable Profitabilitas sebesar 9.464, dengan asumsi variabel bebas yang lain tetap (X1, $\mathrm{X} 2, \mathrm{X} 3, \mathrm{X} 4, \mathrm{X} 5, \mathrm{X} 6$, dan X7 =0) atau Cateris Paribus.

\section{b. Hasil Pengujian Hipotesis}

Hipotesis yang akan diuji ada dua dengan menggunakan multiple regresion. Tujuannya adalah untuk mengetahui apakah Variabel Independen : Variabel Kepemilikan Manajerial (X1) dan Kepemilikan Institusional (X2), serta variabel kontrol : Pembayaran Deviden (X3), Ukuran Perusahaan (X4), Struktur Aktiva (X5), Earning Volality (X6), Stock Volality (X7), dan Profitabilitas (X8) berpengaruh terhadap variabel dependen kebijakan hutang (Y). Berikut ini hasil perhitungan F, t dan R2.

\section{1) Pengujian Hipotesis Pertama}


Untuk menunjukkan apakah semua variabel bebas yang dimasukkan dalam model mempunyai pengaruh signifikan secara bersama-sama terhadap variabel terikat digunakan uji F. Berikut ini adalah tabel yang menunjukkan hasil uji F $\square \square \square \square \square \square$.

Tabel pengujian secara Serentak (Simultan)

\begin{tabular}{|l|l|l|l|}
\hline & Pernyataan & Nilai & Status \\
\hline & $\begin{array}{l}\text { Terdapat pengaruh yang signifikan } \\
\text { secara serentak dari kepemilikan }\end{array}$ & $\mathrm{F}=34.681$ & H1o \\
ditolak / \\
$\begin{array}{l}\text { Manajerial, Kepemilikan } \\
\text { Institusional, Pembayaran Dividen, }\end{array}$ & & H1a \\
diterima \\
Ukuran Perusahaan, Struktur Aktiva, & & \\
$\begin{array}{l}\text { Earning Volatility, Stock Volatility, } \\
\text { dan Profitabilitas berpengaruh } \\
\text { terhadap kebijakan hutang }\end{array}$ & & \\
\hline
\end{tabular}

\section{2) Pengujian Hipotesis Kedua}

Untuk menunjukkan apakah variabel bebas secara individu mempunyai pengaruh yang signifikan terhadap variabel terikat serta untuk membuktikan variabel manakah yang paling dominan maka digunakan uji t dan koefisien Beta yang telah distandarisasi. Berikut ini adalah table yang menunjukkan hasil uji t dan besarnya t table pada signifikansi $5 \%$ dua sisi :

Tabel pengujian secara Parsial

\begin{tabular}{|c|c|c|c|}
\hline $\mathrm{H}$ & Pernyataan & Nilai & Keterangan \\
\hline 1 & $\begin{array}{l}\text { Variabel Kepemilikan Manajerial } \\
\text { berpengaruh terhadap Kebijakan } \\
\text { Hutang (Y) }\end{array}$ & $\begin{array}{l}\mathrm{t}=5.180 * \\
\text { Sig } \mathrm{t}=0.000 \\
\text { Ttabel }=-1.684\end{array}$ & $\begin{array}{l}\text { Ho2a } \\
\text { ditolak / } \\
\text { Ha2a } \\
\text { diterima }\end{array}$ \\
\hline 2 & $\begin{array}{l}\text { Variabel Kepemilikan Institusional } \\
\text { berpengaruh terhadap Kebijakan } \\
\text { Hutang (Y) }\end{array}$ & $\begin{array}{l}t=2.165^{*} \\
\text { Sig } t=0.035 \\
\text { Ttabel }=1.684\end{array}$ & $\begin{array}{l}\text { Ho2a } \\
\text { ditolak / } \\
\text { Ha2a } \\
\text { diterima }\end{array}$ \\
\hline 3 & $\begin{array}{l}\text { Variabel Pembayaran Dividen } \\
\text { berpengaruh terhadap Kebijakan } \\
\text { Hutang (Y) }\end{array}$ & $\begin{array}{l}\mathrm{t}=-2.308 \\
\text { Sig } \mathrm{t}=0.025 \\
\text { Ttabel }=1.684\end{array}$ & Signifikan \\
\hline 4 & $\begin{array}{l}\text { Variabel Ukuran Perusahaan } \\
\text { berpengaruh terhadap Kebijakan } \\
\text { Hutang (Y) }\end{array}$ & $\begin{array}{l}\mathrm{t}=-1.126 \\
\text { Sig } \mathrm{t}=0.266 \\
\text { Ttabel }=-1.684\end{array}$ & $\begin{array}{l}\text { Tidak } \\
\text { Signifikan }\end{array}$ \\
\hline 5 & $\begin{array}{l}\text { Variabel Struktur Aktiva } \\
\text { berpengaruh terhadap Kebijakan } \\
\text { Hutang (Y) }\end{array}$ & $\begin{array}{l}\mathrm{t}=0.953 \\
\text { Sig } \mathrm{t}=0.345 \\
\text { Ttabel }=1.684\end{array}$ & $\begin{array}{l}\text { Tidak } \\
\text { Signifikan }\end{array}$ \\
\hline 6 & $\begin{array}{l}\text { Variabel Earning Volatility } \\
\text { berpengaruh terhadap Kebijakan } \\
\text { Hutang (Y) }\end{array}$ & $\begin{array}{l}\mathrm{t}=4.150 \\
\text { Sig } \mathrm{t}=0.000 \\
\text { Ttabel }=1.684\end{array}$ & Signifikan \\
\hline 7 & $\begin{array}{l}\text { Variabel Stock Volatility } \\
\text { berpengaruh terhadap Kebijakan } \\
\text { Hutang (Y) }\end{array}$ & $\begin{array}{l}\mathrm{t}=1.810 \\
\text { Sig } \mathrm{t}=0.077 \\
\text { Ttabel }=1.684\end{array}$ & $\begin{array}{l}\text { Tidak } \\
\text { Signifikan }\end{array}$ \\
\hline 8 & $\begin{array}{l}\text { Variabel Profitabilitas berpengaruh } \\
\text { terhadap Kebijakan Hutang (Y) }\end{array}$ & $\begin{array}{l}\mathrm{t}=2.162 \\
\text { Sig } \mathrm{t}=0.036 \\
\text { Ttabel }=1.684\end{array}$ & Signifikan \\
\hline
\end{tabular}




\section{a. Variabel Kepemilikan Manajerial}

Variabel Kepemilikan Manajerial memiliki nilai statistik sebesar 5.180. Nilai ini lebih besar dari t tabel ( $5.180>1.684)$. Dengan demikian pengujian menunjukkan Ha2a diterima atau Ho2a ditolak. Hasil ini memperlihatkan bahwa hipotesis yang pertama terbukti dimana variable Kepemilikan Manajerial berpengaruh secara signifikan dan berhubungan positif terhadap Kebijakan hutang. Hasil tersebut sesuai dengan penelitian Wahidahwati (2001), Taswan (2003), Moh'd et al (1998), Bathala et al (1994) serta Jensen dan Meckling (1976) yaitu kepemilikan saham oleh pihak manajemen berhubungan negatif dengan penggunaan hutang. Jensen dan Meckling (1976) dalam Wahidahwati (2001) menyatakan jika manajer memiliki kepemilikan saham yang tinggi dalam perusahaan, maka mereka akan mengurangi tingkat utang secara optimal sehingga akan mengurangi biaya keagenan utang.

b. Variabel Kepemilikan Institusional

Variabel Kepemilikan Institusional memiliki nilai statistik sebesar 2.165. Nilai ini lebih besar dari t tabel ( $2.165>1.684)$. Dengan demikian pengujian menunjukkan Ha2b diterima atau Ho2b ditolak. Hasil ini memperlihatkan bahwa hipotesis yang kedua terbukti dimana variable Kepemilikan Institusional berpengaruh secara signifikan dan berhubungan positif terhadap Kebijakan hutang. Hasil penelitian ini konsisten dengan teori dan penelitian sebelumnya yang dilakukan oleh Bathala (1994), Moh'd (1998), Wahidahwati (2001), dan Fuad (2005). Hasil penelitian ini mengindikasikan bahwa kehadiran institutional ownership pada industry manufaktur yang terdaftar di Bursa Efek Indeonesia (BEI) dapat memonitor perilaku manajemen, semakin besar presentase kepemilikan saham yang dimiliki oleh institusi akan menyebabkan usaha monitoring semakin efektif, karena dapat mengendalikan perilaku oportunistik yang dilakukan manajemen. Dengan tingkat kepemilikan yang tinggi akan mengurangi biaya keagenan pada perusahaan serta penggunaan hutang oleh manajemen. Adanya kontrol ini akan menyebabkan manajemen menggunakan hutang pada tingkat yang rendah untuk mengantisipasi kemungkinan terjadinya financial distress dan risiko keuangan (Ctrutchley et al, 1999 dalam Wahyudi dan Pawestri, 2006).

c. Variabel Kontrol

1) Variabel Pembayaran Deviden

Variabel Pembayaran Deviden memiliki nilai statistik sebesar 2.308. Nilai ini lebih besar dari t tabel $(2.308>1.684)$. Hasil ini memperlihatkan bahwa variabel Pembayaran Deviden berpengaruh secara signifikan terhadap Kebijakan hutang. Hasil ini konsisten dengan penelitian yang dilakukan oleh Wahidahwati (2001) dan Taswan (2003), Ismiyanti dan Hanafi (2003), sedangkan arah hubungan ini konsisten dengan teori dan penelitian Moh'd et al (1998) bahwa pembayaran dividen mempunyai pengaruh negatif terhadap kebijakan hutang, pembayaran dividen akan mengurangi sumbersumber yang dikendalikan oleh manajemen, sehingga untuk membiayai kegiatan operasionalnya manajemen harus mencari sumber pendanaan yang relevan melalui right issue atau hutang.

2) Variabel Ukuran Perusahaan

Variabel Ukuran Perusahaan memiliki nilai statistik sebesar - 1.126. Nilai ini lebih besar dari t tabel (-1.126>-1.684). Hasil ini memperlihatkan bahwa variabel Ukuran Perusahaan tidak berpengaruh secara signifikan terhadap Kebijakan Hutang. Arah dari hubungan mengindikasikan bahwa perusahaan manufaktur BEI tidak meningkatkan penggunaan hutang walaupun terjadi peningkatan total aktiva perusahaan. 


\section{3) Variabel Struktur Aktiva}

Variabel Struktur Aktiva memiliki nilai statistik sebesar 0.168. Nilai ini lebih kecil dari t tabel $(0.953<1.684)$. Hasil ini memperlihatkan bahwa variabel Struktur Aktiva tidak berpengaruh secara signifikan terhadap Kebijakan hutang. Hasil tersebut sesuai dengan Ismiyanti dan Hanafi (2003) dimana variabel aset tetap mempunyai hubungan positif tetapi tidak signifikan terhadap kebijakan hutang. Arah hubungan dalam penelitian ini sudah sesuai dengan penelitian sebelumnya, bahwa aset tetap yang tinggi merupakan kolateral sehingga perusahaan dipercaya oleh pemberi hutang (debtholder).

4) Variabel Earning Volality

Variabel Earning Volality memiliki nilai statistik sebesar 4.150. Nilai ini lebih besar dari t tabel (4.150 > 1.684). Hasil ini memperlihatkan bahwa variabel Earning Volality berpengaruh secara signifikan terhadap Kebijakan hutang. Hasil ini konsisten dengan studi Taswan (2003) dan Christianti (2006), hal ini menunjukkan bahwa dalam hubungannya dengan volalitas laba, perusahaan manufaktur di BEI masih cenderung menggunakan hutang pada tingkat yang tinggi ketika earning volality tinggi. Kemungkinan hal ini terjadi karena adanya perbedaan kepentingan antara insider dan outsider yang menyebabkan terjadinya biaya keagenan ekuitas. Biaya keagenan ekuitas terjadi karena manajer cenderung menggunakan hutang yang tinggi bukan atas maksimalisasi nilai perusahaan akan tetapi untuk kepentingan opportunistik. Menurut Chen et al (1998) dalam Christianty (2006) dalam hubungannya dengan Agency Theory, hubu

\section{Kesimpulan}

Kesimpulan terhadap hasil penelitian yang telah dilakukan berdasarkan pada tujuan penelitian, tinjauan pustaka, metodologi penelitian, serta analisis dan interpretasi yang telah dijelaskan pada bab sebelumnya. Adapun kesimpulan dari hasil penelitian sebagai berikut:

a. Kepemilikan Manajerial dan Kepemilikan Institusional secara simultan (serentak) berpengaruh signifikan terhadap kebijakan hutang. Hasil tersebut konsisten dengan penelitian Wahidahwati (2001) yang menyatakan bahwa semua variabel yang mencerminkan biaya keagenan pada industri manufaktur yang go publik di BEI dapat digunakan sebagai instrumen penentu kebijakan hutang untuk meminimumkan total biaya keagenan.

b. Kepemilikan Manajerial secara parsial berpengaruh signifikan dan berhubungan negatif terhadap Kebijakan Hutang perusahaan. Hasil tersebut konsisten dengan penelitian Wahidahwati (2001), Taswan (2003), Moh'd et al (1998), Bathala et al (1994) serta Jensen dan Meckling (1976) yaitu kepemilikan saham oleh pihak manajemen berhubungan negatif dengan penggunaan hutang. Kepemilikan Manajerial merupakan faktor penting yang mempengaruhi Kebijakan Hutang, hal ini kemungkinan disebabkan masih sejajarnya kepentingan antara manajer dan pemegang saham.

c. Kepemilikan Institusional secara parsial berpengaruh signifikan dan berhubungan negatif terhadap kebijakan hutang perusahaan. Hasil penelitian ini konsisten dengan teori dan penelitian sebelumnya yang dilakukan oleh Bathala (1994), Moh'd et al (1998), Wahidahwati (2001), dan Fuad (2005). Moh'd et al (1998) menyatakan kepemilikan institusi mewakili suatu sumber kekuasaan (source of power) yang dapat mendorong peningkatan pengawasan yang lebih optimal terhadap kinerja manajemen. Sehingga, manajemen cenderung lebih berhati-hati dalam menggunakan hutang. 
d. Berdasarkan variabel kontrol yang digunakan dalam penelitian, Earning volality dan Profitabilitas memiliki pengaruh yang signifikan terhadap Kebijakan Hutang. Sedangkan yang lainnya memiliki pengaruh yang tidak signifikan tetapi arah dari hubungan terhadap Kebijakan Hutang konsisten dengan penelitian sebelumnya.

\section{Daftar Pustaka}

Wahidahwati 2002 Pengaruh Kepemilikan Manajerian dan Kepemilikan Institusional Pada Kebijakan Hutang Perusahaan : Sebuah Perspektif Theory Agency, Jurnal Riset Akutansi Indonesia Vol. 5 No 1 Januari Hal 1-16

Beny, 2013, Pengaruh Dividen Payout, Profitabilitas, Pertumbuhan Perusahaan, Kepemilikan Manajerial,

Kepemilikan Institusional dan Aliran Kas Bebas terhadap Kebijakan Hutang. Jurnal Bisnis dan Akuntansi Vol.15, No.2. Hlm : 168-176.

Brigham, Eugene F.dan Joel F Houston, 2011, Dasar-Dasar Manajemen Keuangan, Jakarta : Salemba Empat.

Brigham, Eugene F, dan Joel F. Houston, 2012, Dasar-dasar Manajemen Keuangan Edisi Kesebelas, Jakarta : Salemba Empat.

Brigham, Eugene F dan Houston, Joel F, 2013, Dasar-dasar Manajemen Keuangan Buku 1 Edisi 10. Jakarta : Salemba Empat.

Brealey, Myers, Marcus, 2008, Dasar-Dasar Manajemen Keuangan, Perusahaan, Jilid Jakarta: Erlangga

Indahningrum, Rizka Putri, dan Ratih Handayani, 2009, Pengaruh Kepemilikan Manajerial,Kepemilikan Instritusional, Dividen, Pertumbuhan Perusahaan, Free Cash Flow, Profitabilitas terhadap Kebijakan Hutang. Jurnal Bisnis dan Akuntansi. Vol.11, No.3. Hlm :189-207.

Jensen, Michael C. And W.Meckling, "Theory of the Firm : Managerial Behavior Agency Cost, and Ownership Structure," Journal of Finance Economics Vol. 3, No. 4, Oktober 1976.

Kasmir, 2008, Bank dan Lembaga Keuangan Lainnya. Edisi Revisi 2008, Jakarta: PT.RAJAGRAFINDO PERSADA.

Larasati, Eva, 2011, Pengaruh Kepemilikan Manajerial, Kepemilikan Institusional dan Kebijakan Dividen

Terhadap Kebijakan Hutang Peusahaan. Jurnal Ekonomi Bisnis, No. 2.

Mardiyanto, Handono, 2009, Intisari Manajemen Keuangan, PT Grasindo: Jakarta.

Murtiningtyas, Andika Inova, 2012, Kebijakan Dividen, Kepemilikan Manajerial, Kepemilikan Institusional,

Profitabilitas, Risiko bisnis terhadap Kebijakan Hutang. Accounting Analysis Journal. Vol.1, No. 2.

Pearce, J.A. dan Robinson, R.B, 2008, Manajemen Strategis: Formulasi, Implementasi dan Pengendalian, Penterjemah Yanivi Bahtiar, Jakarta: Salemba Empat.

Sugiyono, 2010, Metode Penelitian Kuantitatif Kualitatif dan R\&D, Penerbit Alfabeta, Bandung. Sugiyono, 2012, Metode Penelitian Bisnis, Penerbit Alfabeta, Bandung. 
Van Horne, James C., dan Wachowicz, JR, John M. 2007. Prinsip-prinsip Manajemen Keuangan. Edisi 12. Jakarta: Salemba Empat.

Wuryaningsih D.L, 2007. Pengujian Pengaruh Capital Structure Pada Debt Policy (Studi Empiris Pada Perusahaan Manufaktur Di Indonesia). BENEFIT. vol. 8, No. 2. Hlm: 41-56.

Pengaruh Kepemilikan Institusional, Kepemilikan Manajerial dan Kebijakan Dividen terhadap Kebijakan Hutang Pada Perusahaan Manufaktur yang Terdaftar Di Bursa Efek Indonesia Tahun 2012- 2014 http://ejournal.ukanjuruhan.ac.id Hal | 15

Yeniatie dan Nicken Destriana, 2010, Faktor- Faktor yang mempengaruhi Kebijakan Hutang pada Perusahaan

Non Keuangan yang terdaftar di Bursa Efek Indonesia, Jurnal Bisnis dan Akuntansi. Vol.12, No.1. Hlm: 1-16.

Yohana, Denny dan Warnida, 2008, Pengaruh Konsentrasi Kepemilikan, Klasifikasi Industri, Pertumbuhan Risiko Terhadap Leverage Perusahaan Publik Di Indonesia. Jurnal Penelitian Akuntansi-Fakultas EkonomiUniversitas Gunadarma, Juni 2008.

Jensen, Michael C. and Meckling, William H., Theory of the Firm: Managerial Behavior, Agency Costs and Ownership Structure (July 1, 1976). Michael C. Jensen, A THEORY OF THE FIRM: GOVERNANCE, RESIDUAL CLAIMS AND ORGANIZATIONAL FORMS, Harvard University Press, December 2000, Journal of Financial Economics (JFE), Vol. 3, No. 4, 1976 